more resemblance to a dental fragment of Notidanus than the Swabian fossil described by Oppel, as far as the latter's figure will enable one to judge. It does not agree with the teeth of Palaospinax or any other Liassic Shark I have had the opportunity of studying, and Tate and Blake's determination is very possibly correct; but more satisfactory evidence must still be awaited before there is absolute certainty of the presence of Notidanus among the early Jurassic fauna.

A. SMith Woodward.

\title{
ENTOMOSTRACA IN THE RHETICS.
}

Sir,-In the Geological Magazine, May, 1886, p. 203, a slight error occurs in Mr. J. S. Gardner's interesting paper, in stating that "the valves of a species of Cyclas abound in the Rhætics." This should have been either Candona or possibly Cypris; the latter may be after all correct, as it is associated with the freshwater aquatic Moss, Naiadites. The supposed Cyclas has been determined to be Estheria, a brackish-water.Crustacean, though Sowerby stated it to be Cyclas, when my work on Fossil Insects was published. In the Note (2) at the bottom the reference should have been not to the Estheria bed in particular, but to the Rhætics in general (in which the former is included), which may be considered to be junction or passage beds between the Trias and the Lias.

\section{P. B. Brodiz.}

\section{OPITUAEY. \\ HARVEY BUCHANAN HOLL, M.D., F.G.S.}

Born 28th Septemaer, 1820; Difd 11Th Skptember, 1886.

THIs able geologist and palæontologist was son of the late William Holl, Esq., formerly of Worcester. After passing through Dr.Walter's School at Worcester, he entered the Medical College in Birmingham.

During this period of Harvey Holl's career, when he was only about 17 years of age, he became acquainted with Sir Henry de la Beche, and was invited by that distinguished geologist to accompany him in a geological reconnaissance through Devon and Cornwall. It was probably owing to this expedition (which extended over some six months) that young Holl became confirmed in his geological tastes, and for a time was led entirely to abandon his medical studies.

From the good opinion which Sir Henry de la Beche formed of Holl's work in the field, he recommended the youthful geologist to his friend Professor Rogers, of Philadelphia (who was seeking an assistant), and Harvey Holl started off to join his new chief and take a part in the Geological Survey of Pennsylvania. In this interesting region, Holl remained for about three years, and spent a year longer in the United States geologising on his own resources.

Upon his return to England, Holl entered as a student at St. George's Hospital, and successfully passed the Royal College of Surgeons in London. In 1859 he graduated as M.D. at King's College, Aberdeen. 